\title{
Sieges in the Mediterranean World
}

\author{
Jeremy Armstrong and Matthew Trundle †
}

Urban warfare in the Middle East today is characterised by the increasing use of an ancient form of urban warfare: the siege. In 2016, eastern Aleppo was subjected to a well-known siege that lasted 190 days; the obstruction of humanitarian assistance caused massive suffering among civilians in many other Middle Eastern towns and cities as well, such as Fallujah, Taiz, Deir Ezzor, Foua, Kefraya and Madaya. In the Syrian Old City of Homs, which was under siege from May 2012 to May 2014, cart seller Abu Hani says that his family gathered firewood in the streets at night, as there was no diesel or gas to be had and they could not move around during the day because of the fighting. Because of shortages of food, he adds, people tried to grow their own vegetables but they often had to resort to eating partially rotten lentils and plants growing in the street that, in normal circumstances, were not considered edible. 'We lost a lot of weight [during this time],' Hani says. 'One does not think about food when one is afraid, one meal is enough.' In some cases, cities in conflict are virtually under siege because of the extreme difficulty of taking goods in or out. The partial siege imposed on Taiz since the summer of 2015 has brought the local economy to the point of collapse. 'Most markets in the city have closed, and in those that still have some food, the prices are so high that people do not have enough money to buy anything,' says Nancy Hamad, who runs the ICRC's office in Taiz. 'Malnutrition cases have gone up very sharply, especially among children.' 'People are eating from the garbage because they can't get food,' she adds. 'We've seen women boiling tree leaves just to give children some hot soup.' Fighting in or around a besieged city can also cause the destruction of harvests in fields within the city or on its outskirts, or make the fields inaccessible. At one camp for internally displaced people, children who had recently left a city under siege recall times of bitter hunger. 'I can't remember the last time I saw a chicken or a sheep,' says one child. ${ }^{1}$

1 'I saw my city die'-International Committee of the Red Cross (2017). 
No other military encounter comes as close to a 'total war' experience as the siege of a major city. While, in some instances, civilians are able to evacuate a settlement in advance of (or during) a besiegement, in many cases both civilians and soldiers are thrust together into the heart of the conflict. Indeed, even in cases where evacuation is possible, displacement offers its own, very real, dangers - as recent refugee crises illustrate. Starvation, oppression, and loss of freedom and identity are not only dangers for those who remain within the city.

The siege threatens the entire community and involves every member of society directly in war. It is not a distant battlefield encounter between adult, male soldiers. Women, children, and (in antiquity) slaves stand side by side with men, both rich and poor, against attack-indeed, even the term 'noncombatant' (at least amongst the defenders) becomes problematic in these contexts. For all the defenders, the siege is an absolute moment of survival or destruction - an encounter which decides life or death, slavery or freedom. Though, arguably, the women and children suffer far more than their male counterparts if the city falls. Unlike a battle on an open field, defeat following a siege typically offered little chance for escape-there was often nowhere to run. The siege is the 'hell' of war brought home. These points are as true today as they were in antiquity.

One hot and sticky evening in July, in the dying days of the battle for Mosul, a group of Iraqi army officers sat for dinner in a requisitioned civilian house not far from the ruins of the mosque where, three years earlier, the leader of Islamic State had announced the creation of a new caliphate ... Over the previous eight months, since the commander and his men had started fighting in Mosul, the caliphate had shrunk to a tiny sliver of the Old City squeezed between the River Tigris and advancing columns of army and police forces. Thousands of ISIS fighters, who captured the city in 2014, were now trapped, living without running water or electricity, with dwindling supplies of food and medicine, being bombed day and night by US drones and jets. Caught in the siege with them were thousands of civilians. The few who were managing to escape came out filthy, emaciated and crazed by thirst and the constant bombing. The officers at dinner that night were all veterans of the war against ISIS, but nothing in their long years of fighting compared to what they had experienced over the past few weeks in Mosul, one of the fiercest urban battles since the Second World War. They fought in narrow alleyways, old stone houses and dense networks of tunnels and basements. Their advance was sometimes measured in meters, and their casualties were mounting. ${ }^{2}$

2 'After the liberation of Mosul, an orgy of killing' The Guardian, 21 Nov 2017. 
On the other side of the coin, besiegers, encamped in what is often enemy (or at least contested) territory, also exposed themselves to disease, counter-attack, and counter-encirclement. Their position was often known and their mobility limited by the besiegement. The static circumstances of the besiegers would have exacerbated all of the threats which normally confronted an army on campaign. An army besieging a settlement was often at its most vulnerable and exposed. Famously, both the Athenians at Syracuse in 413 BC and the Germans at Stalingrad in 1942/3 saw the tables turned as besiegers became besieged and invasion became disaster. The tension, stress, and frustration of maintaining a siege must have been immense-something perhaps seen in the often savage behaviour of soldiers within a city once the walls had been breached. The expending of their pent-up rage.

Alexander [after capturing the city of Tyre] gave orders that all except those who had taken refuge in the temples should be slain and the houses set on fire. Although this order was proclaimed by heralds, yet not a single armed man could bring himself to seek aid from the gods; boys and maidens had filled the temples, the men stood each in the vestibule of his own house, a throng at the mercy of the raging foe ... But how great the bloodshed was may be calculated from this alone, that 6000 armed men were butchered within the city's ramparts. After that the king's wrath furnished the victors with an awful spectacle; 2000 men, for the slaying of whom frenzy had spent itself, hung nailed to crosses along a great stretch of the shore. ${ }^{3}$

The siege transformed warfare, and particularly ancient warfare. It turned what was typically a short, seasonal endeavour, defined by brief but intense actions between groups of men, into what was often a long and gruelling struggle involving a much wider segment of the population. It redrew social divisions and reshaped social and cultural norms. Indeed, sieges represent an area of warfare where many of the normal 'rules of war' are subverted. In modern times, these circumstances have often led to atrocities and war crimes. In antiquity, the same was also likely true-although not formally defined as such. Additionally, even broad cultural norms were often inverted, with military innovation being lauded, and not despised, and trickery, strategy, and technology all becoming accepted in siege contexts. There was also a fundamental breakdown of social and political order brought about by the need to

3 Curt. 4.4.13-18 (trans. Rolfe). 
fully mobilise the population and the unified nature of the threat. Women and children could kill kings, as Plutarch notes-'But Lysander threw away his life ingloriously, like a common targeteer or skirmisher, and bore witness to the wisdom of the ancient Spartans in avoiding assaults on walled cities, where not only an ordinary man, but even a child or a woman may chance to smite and slay the mightiest warrior, as Achilles, they say, was slain by Paris at the gates.' (Plut. Comp. Lys and Sull. 4.3, trans. Perrin). Similarly, Pyrrhus of Epirus died from a roof-tile thrown by an 'old-woman' in street fighting in the city of Argos in the Peloponnese (Plut. Pyr. 34.2). A siege was (and is) chaotic, brutal, and terrifying for all involved.

Given its abnormal character and intense 'total war' aspect, it is unsurprising that sieges play a central role in the history, myths, and legends of ancient peoples. Sieges stand out in communal memory. They are not easily forgotten-although their intrinsic memorability obviously does not mean they are not also reshaped in the collective memory. Sieges could be symbolic, for instance of either a god's pleasure or wrath. The Hebrews remembered the walls of Jericho falling to the trumpets of Joshua, divinely endorsing their entrance into the 'Promised Land'. Jerusalem, a talismanic centre of identity, fell time and again to assault with each instance laden with meaning, including to the Romans in AD 7O- an event famously recalled on the 'Arch of Titus' in the Roman Forum. And of course, Jerusalem was not the only city to fall to the Romans: Capua fell in $211 \mathrm{BC}$, New-Carthage in $209 \mathrm{BC}$, and Carthage itself in $146 \mathrm{BC}$. Indeed, sieges were both a mechanism and expression of earthly power as well. Caesar's siege of Alesia in $5^{2} \mathrm{BC}$ effectively ended Gallic freedom. The Assyrians stamped their mark on antiquity with impressive siege machines and their ability to assail city walls through technology. Assyrian kings depicted this technology in fabulously detailed bas-reliefs on the walls of their palaces. Sieges ranked among Alexander's greatest achievements, and the capture of the island fortress-city of Tyre stands in particular as a fantastic feat of engineering and ingenuity.

Sieges were also, perhaps paradoxically, foundational. The Romans recalled the siege of Veii as a defining moment in their past, followed soon after by the equally formative siege and fall of their own city to the Gauls of Brennus c. 39o BC, leading to the 'rebirth' ('secunda origine' Livy 6.1.3) of Rome. Most significant of all, the Trojan War represented for both the Greeks and the Romans not only a 'total war' experience, but also a paradigmatic foundation myth for both peoples. Homer's great epics, the Iliad and Odyssey, are part of a cycle of poems concerned with the siege of Troy-the greatest event of the Heroic Age. Troy's siege combined elements of blockade and assault. The Trojan Horse represents perhaps the most famous war-machine (or ruse de guerre?) made in 
antiquity. It was a device designed to deceive the enemy, to penetrate the walls through guile. The sack of Troy resonated with pathos, the murder of Priam, the destruction of his city, and the enslavement of women and children continue to provide material for art and literature even today. The return of the Greeks to their homes and even the flight of the survivors under Aeneas to Italy gave the aftermath of siege an afterlife.

Like their ancient counterparts, sieges from subsequent periods also often seem to rise above the parapets of the narrative in the minds of writers and artists. The medieval period saw the construction of fantastic castles, built to withstand the most ferocious attacks; imposing crenelated walls confronting any who would attack them across daunting moats. Castles dominated the landscape of Europe and, as the crusaders moved east, so their castles dotted the Mediterranean and the Middle East. These structures (and assaults upon them) defined the narrative for and depiction of (as well as the later reception of) the warfare of the age. Moving later still, the Second World War presents a series of major encounters on the eastern front that defined the struggle between Germany and Russia from Stalingrad, to Leningrad, and Berlin. Each of these have been the subject of major and bestselling histories. In more recent times, the sieges of Homs, Mosul, and other Middle Eastern cities have also dominated the headlines-putting a human face on the Syrian civil war and the international fight against Daesh (ISIS). The suffering of these cities, and of the refugees who fled from them, has served to define the conflicts. The terrible and wide-ranging impact of the siege seems to have lost none of its vigour over the millennia. Indeed, as cities have grown larger and more complex, the impact of sieges has arguably grown more profound.

Sieges could take on many forms and did not always involve heated battle. Many sieges were concluded without a blow being struck - although not, perhaps, without a life being taken. At the core of a siege is the concept of blockade, and notions of blockade and deprivation/starvation go hand in hand with wider strategic concerns of military planning and logistics in complex wars. The horrors of these aspects of siege warfare are just as visceral as that of combat, if not more so. As Deuteronomy 28:53-57 suggests, in the first account of a siege in the Bible, starvation and cannibalism were clear threats:

And thou shalt eat the fruit of thine own body, the flesh of thy sons and of thy daughters, which the Lord thy God hath given thee, in the siege, and in the straitness, wherewith thine enemies shall distress thee: So that the man that is tender among you, and very delicate, his eye shall be evil toward his brother, and toward the wife of his bosom, and toward the 
remnant of his children which he shall leave: So that he will not give to any of them of the flesh of his children whom he shall eat: because he hath nothing left him in the siege, and in the straitness, wherewith thine enemies shall distress thee in all thy gates. The tender and delicate woman among you, which would not adventure to set the sole of her foot upon the ground for delicateness and tenderness, her eye shall be evil toward the husband of her bosom, and toward her son, and toward her daughter, and toward her young one that cometh out from between her feet, and toward her children which she shall bear: for she shall eat them for want of all things secretly in the siege and straitness, wherewith thine enemy shall distress thee in thy gates. ${ }^{4}$

Jeremiah (19:9) also picks up on this theme of the horrific results of the blockades associated with a siege ('And I will cause them to eat the flesh of their sons and the flesh of their daughters, and they shall eat every one the flesh of his friend in the siege and straitness, wherewith their enemies, and they that seek their lives, shall straiten them.' KJV). This is furthered in the account of Ben Hadad of Aram's siege of Samaria, the capital of Israel in the 79os BC (II Kings 6:25). As the siege continued, famine in Samaria became so great that a donkey's head was sold for the outrageous price of eighty shekels of silver, and one-fourth of a kab of dove's dung for five shekels of silver.

The siege is therefore a rather blunt instrument of war, which typically inflicts the greatest harm on the weakest members of society. It deprives soldiers of provisions, but also the civilians. And those who are often first and most affected by the sufferings inflicted by sieges (as in other cataclysmic events) will be those who are lowest on the socio-economic ladder; those with little power and few resources.

It is important to realise that sieges were products not just of attack, but of defence. A siege often (although not always) resulted when there was an imbalance of military power, with the weaker side eschewing direct engagement and compensating for its lack of strength through the use of technology and static defences. Fortifications offered a way to accumulate and stockpile military power, albeit in a fixed location. The emergence of walled cities likely developed, in many contexts, in tandem with the ability to assault them. Thus, technologies of assault-from simple ladders to impressive siege towers and ballistae - often emerged and evolved in response to, and in dialogue with, improved defensive structures. There was a natural symbiosis between walled

4 Deut. 28:53-57 (KJV). 
cities and the technology used to attack them, although these facets did not exist in isolation. Nor were they always evident. In archaic Italy, for instance, fortifications seem to have developed well before the ability to mount full-scale besiegements, and indeed before widespread urbanisation. ${ }^{5}$ In this context, walls may have served as limited protection from raiding - a refuge in times of need. Social and cultural considerations also always underpinned and shaped the relationship between warfare and society. Indeed, as often noted in discussions of the great walls of Mycenae, fortifications were rarely if ever intended strictly as means of defence against an attack. Walls are symbolic. They separate 'us' from 'them' and help to define civic entities. Their scale and construction also offer an overt expression of wealth and power. Although a siege may impact those lowest on the socio-economic spectrum the most, the walls which help to protect the soldiers (and arguably prolong the siege), represent those at the other, and highest, level.

A crucial question also remains concerning the extent to which a siege stands aloof from other forms of military action; from raiding, or pitched battles, and long-ranging campaigns. Sieges often involved, or were part of, all of the above. Similar, and yet somehow different as well. And returning to the concept of a ruse de guerre, one must also consider the role which trickery and bribery played in the conclusion of so many sieges. These engagements were often low-intensity and involved the two sides facing each other for many days, weeks, possibly months, and even years. In this time, negotiation and interaction often occurred. Indeed, the number of times where bribery and subterfuge proved decisive indicates that this was not limited to strict official channels. There was likely quite a bit of interaction between the two sides of a siege which did not involve combat.

Taken as a whole then, the siege is curiously both ubiquitous and anomalous in the Mediterranean basin. It is what happens when an activity that is typically meant to occur outside the bounds of civilised society violently reenters that sphere-bringing the horrors of war to an entire community. In this regard, siege warfare was rarely desirable, for either side. And indeed, those that seem to invite it - as with Periclean Athens - often live to regret the decision. However, despite its seemingly unnatural character, sieges have been common in the Mediterranean, with its long history of urbanism. ${ }^{6}$ With early evidence from Egypt and the Near East, as long as we have had stable communities, we seem to have had assaults on communities. The study of siege warfare then,

5 See Fontain and Helas (2016) for discussion.

6 For the link between urbanism and fortifications see Butterlin and Rey (2016) 23-33. 
allows an insight into the nature of both warfare and society. Sieges seem to push the boundaries of ancient norms, and the way they do that can be illuminating.

Interestingly then, ancient siege warfare has not, perhaps, enjoyed as prominent a place in the modern historiography of ancient warfare as one might expect. This point is made clearly in the most recent study of sieges in the 'Near East'. Israel Eph'al in his 2009 book The City Besieged: Siege and Its Manifestations in the Ancient Near East rightly states that 'To date, there has only been limited discussion of the phenomenon of siege warfare in the ancient Near East.' (p. 3). This is remarkable given that, for example, peoples like the Assyrians are so well known for, and connected to, siege machines; their iconography illustrates vividly their abilities to overcome walled cities with tunnels, rams, and towers. Historically, Greco-Roman sieges and the related subject of fortifications have been served slightly better with several important studies. F.E. Winter's Greek Fortifications provides an excellent introduction to the subject. More recently still Rune Frederikson's study of Greek fortifications in the archaic age and Matthew Maher's The Fortification of Arkadian City States in the Classical and Hellenistic Periods explore a number of aspects of the fortifications of the poleis of the central Peloponnese from the midfifth century onwards, from both a literary and archaeological perspective. ${ }^{7}$ These works shed light on the nature of Greek community formation and development through the longue durée of Greek history. Finally, 2016 also saw the publication of an important survey of numerous fortified sites across the ancient world entitled Focus On Fortifications: New Research on Fortifications in the Ancient Mediterranean and the Near East. ${ }^{8}$ Generally, and perhaps more indirectly, siege operations in Greece have also enjoyed several good discussions through a focus on artillery and siege engines. The most notable of these remains Marsden's masterful 1969/1971 Greek and Roman Artillery, and more recently Duncan B. Campbell's analysis of ancient missile technology provides further details. ${ }^{9}$ It is only in recent years that the subject of ancient siege warfare has increasingly seemed to take its proper place in the scholarly consciousness. Studies like Kern's 1999 Ancient Siege Warfare and sections in the The Cambridge History of Greek and Roman Warfare seem to have laid some of the foundation for a recent surge in interest seen, most notably, with works like Levithan's 2013 Roman Siege Warfare and Peterson's 2013 Siege Warfare and Military Organization in the Successor States (400-800AD). These

7 Frederikson (2016) 251-266 and Maher (2017).

8 Frederiksen, Müth, Schneider, and Schnelle (2016).

9 Campbell (2003). 
have been supplemented by an increased understanding of the archaeological context of sieges - most notably in works like Davies 2006 Roman Siege Works and articles by Theocharaki, Bernard, Valbelle, and others exploring the nature of forts and circuit walls. ${ }^{10}$ Several important works on Italian fortifications in particular have also emerged in recent years, most notably Paoletti's 2008 La città murata in Etruria, Bartoloni and Michetti's 2014 Mura di Legno, mura di terra mura di pietra: fortifi cazioni nel Mediterraneo antico and Fontaine and Helas' 2016 Le fortificazioni arcaiche del Latium vetus e dell'Etruria meridionale (IX-VI sec. a.C.). There have also been analyses of ancient texts devoted to the topic — as with Whitehead's 2016 study on Philo Mechanicus: On Sieges.

As these works have shown, the relative lack of scholarly interest in the topic was not due to a lack of evidence. Fortifications offer some of the most visible and durable forms of archaeological evidence and ancient writers regularly offered advice on siege warfare, both from the perspective of the besieger and the besieged. The fourth-century вС writer Aeneas Tacticus (the Tactician) wrote a treatise on How to Survive Under Siege to assist a city's defenders. ${ }^{11}$ Some evidence suggests he also wrote a Poliorcetica advising besiegers. Later writers provided manuals on engineering works including siege machines. We are also blessed with a great deal of indirect information from historians like Herodotus and Thucydides. The former was well aware of the abilities of the Persians to undertake enormous engineering works to undermine city walls or cross moats and Thucydides describes in detail the dangers presented by traitors within cities who might betray their own communities to attackers. Operations around Corcyra and more extensively at Syracuse involved both negotiations, circumvallation, and much intrigue on either side. The fourth century вС witnessed great strides in siege technology. Philip and Alexander undertook impressive sieges whereby cities were assailed by storm. Perhaps most famously and impressively of all, Tyre fell to a combination of an enormous mole and siege towers erected on ships. The subsequent Hellenistic world saw ancient siege technology reach its highest point. This is perhaps not surprising as not only did military resources maximise power, but the combination of Greek, Macedonian, and Persian intellectual developments produced a flourishing of applied military technology. In tandem with siege works and siege machines, fortresscities emerged displaying the most advanced defensive systems. The symbiosis between defence and attack can be seen clearly in this age.

10 Theocharaki (2011); Bernard (2012); and Valbelle (2001).

11 See Pretzler and Barley (2017) for recent discussion. 
Heirs to such technologies, as we have noted briefly above, the Romans captured multiple cities across the Mediterranean. Polybius (especially 10.15.1-5) describes Roman violence in sieges as second to none and details several significant Roman sieges in his account. He was present at the fall of Carthage in $146 \mathrm{BC}$ and he famously recalled the words of his friend, the Roman commander Scipio Aemilianus, on the eve of the city's destruction quoting Homer (Hom. Il. 6.448-449; App. Pun. 19.132.): 'That day will come when Holy Troy shall fall, and Priam Lord of spears and Priam's folk.' Caesar's work The Gallic War culminates with the great siege of Alesia that finally broke the back of Gallic resistance. Alesia represents both a battle and a siege clearly. The Roman besiegers became besieged themselves and the fighting was less about breaking into a city than surviving the Gallic assaults. At Alesia, battle and siege came together in one contest. Plenty of historians of Rome focused on sieges through the Imperial period. We are not starved of source material for the siege in antiquity. Additionally, as touched on previously, the development of archaeology has opened still further avenues for the study of sieges. The nature of fortifications at sites is now increasingly clear, as is the development of siege works. From Hadrian's Wall in Britain to the sand of the Near East, the physical reality of fortifications and sieges are coming into focus. Indeed, looking to the east, excavations like that at Dura-Europos - where the preserved remains of fully equipped soldiers who died fighting in siege tunnels during the siege of Shapur I in AD 256 have been unearthed-have offered a physical context for the vivid narratives offered by the ancients.

This volume offers a wide-ranging overview of current directions in the study of ancient sieges, from ancient Egypt and the Near East, through Greece and the Roman Empire, and ultimately the reception of ancient sieges in later literature. This volume cannot hope to be comprehensive in its coverage, but it does strive to be roughly representative of the way scholarship is moving in this area-and indeed, it is moving. What was once a somewhat intellectual and abstract field of study — dominated by literary tropes, tactical ideals, and moral exempla - is increasingly becoming more 'concrete', through the application of archaeology and modern parallels.

The following chapters divide neatly into several sections commencing with an overview discussion of the role of topography and geomorphology in the decision-making of commanders charged with besieging stubbornly-held targets in the Greco-Roman world. Here Gwyn Davies examines the way in which the landscape served to condition the adoption of a particular reductive ap- 
proach. Davies investigates how the terrain as well as its underlying geology were major components in deciding upon the suite of siege works constructed by the assailant as well as the make-up of these works and their tactical siting (such as the ready availability of stone over timber or the desirability of suppressing the defenders' access to extramural water sources). The chapter explores the importance of provisioning and the readiness of attackers to engage in the sieges of difficult targets in challenging environmental conditions. The author considers whether such approaches could be construed as deliberate and symbolic assertions of power over the defenders and their ancestral landscape rather than the product of a purely utilitarian calculation of the 'least-cost solution' to the task in hand. Indeed, Davies concludes that the successful siege of an 'impregnable' target could be represented not only as a triumph over the defenders, but one over Nature itself.

The volume then continues in a roughly chronological fashion, following the rise and fall of great empires in the Mediterranean basin as the locus of power moves slowly from east to west. The first of these chapters therefore focuses in the Near East and Egypt. Luis R. Siddall discusses the development of siege warfare in the Assyrian military system and so examines the development of siege warfare as a tactic in Assyrian militarism. Many existing studies have looked at Assyrian sieges synchronically, whereas this study aims to identify how it developed over time. The descriptions of the use of sieges in Assyrian royal inscriptions and art remain the primary focus of this chapter, though archaeological material also provides important information. Complementary to Siddall's chapter, Davide Nadali examines Assyrian bas-reliefs (ninth to seventh century BC) as a fundamental source for the study and comprehension of siege in warfare. Many images depict the Assyrian army while involved in the operation of besieging and conquering fortified enemy cities in different environmental and geographical contexts. Nadali sees the images as following a precise 'iconographical canon'. As such, the images of warfare, and sieges in particular, reproduce, on the surface of slabs in the Assyrian palaces, what the Assyrian army effectively did in the field; on the other hand, they also reproduce what the Assyrian artists have seen and therefore their (re)interpretation of the action following the needs of clarity in the visual narratives. Nadali aims at analysing, in a diachronic perspective, the representations of siege by combining different sources (iconography, texts and archaeology). His study seeks to investigate how images of sieges were organised, what they showed, and finally what we can say about the Assyrian siege technique through the only observations of what the Assyrian artists wanted to show and disclose to us. The chapter suggests that the results of the choices of Assyrian artists were an attempt to represent the complexity of (often simultaneous) actions that 
occurred during a siege from Assyrian bas-reliefs. The final result will be a balanced analysis between what the images show and what we can therefore say, passing through a consideration of what we are able to know from the combination of other sources.

Turning to ancient Egypt, Brett H. Heagren's discussion of 'Assault Warfare' in Egypt examines a multitude of temple reliefs and numerous royal and private textual accounts in order to challenge the impression of a static, if not archaic, military machine that was timeless and unchanging. In one area of Egyptian military activity especially, the conduct of assault warfare on fortresses or towns, he argues that we see a remarkable sense of continuity in the pictorial and textual evidence. Heagren concludes that far from supporting the idea of a stagnating war machine, sieges demonstrate key developments in the practice of warfare. The techniques that the Egyptians favoured show a clear preference for low cost and low attrition warfare, especially where limited time and resources were clearly an overriding concern. These elements clearly manifested themselves in Egyptian military activity at the operational level. In short, Heagren suggests, Egyptian preferences of attack reflect a high level of military sophistication, which is not at first apparent.

Staying in Egypt, though looking at a later period, Alan B. Lloyd's analysis of the defence of Egypt in the fourth century вС shows how campaigns were won either by depriving the enemy of the will to fight or by depriving them of the means to do so. In this paper he focuses specifically on the defence of one country (Egypt) in a specific time-frame (the fourth century вс), but against both Persian and Macedonian invaders. Defence may proceed either by an offensive stance against an actual or potential aggressor, by holding a static position, or by a combination of the two. Fortifications, whether designed for attack or defence, can play a major role in such a process, but, like all instruments of war, they form part of a series of approaches for bringing force to bear effectively on the enemy and ensuring that the enemy cannot reciprocate effectively in kind. As such, they cannot be treated in isolation, and their success or failure will depend on a complex interplay of factors many of which are of general validity in the practice of the science of war.

Matthew Trundle explores the introduction of siege technology into the Greek world in the fifth century Bс. Three factors appear crucial to his study in the development of the machinery required to prosecute aggressive siege warfare beyond time-consuming and often intensive circumvallation. The first was the influence of the peoples beyond the Greek world, like the Persians and Carthaginians, on the Greek mainland and Sicily respectively, behind both of whom lay the Assyrians. Secondly, money in the form of coins provided the ability to coordinate and centralise operations so that states like Athens could 
prosecute bigger and more aggressive, intensive warfare. Thirdly and finally, the centralisation that political cohesion provided through the mechanisms of the polis (as at Athens) or through tyrants (Syracuse) or kings (the Macedonians) ultimately enabled the prosecution of more professional and specialised warfare, which included technical siege warfare and the machinery that enabled armies to overcome walled cities more quickly and effectively than previously possible through circumvallation.

Jennifer Martinez Morales takes up the civilian aspect of Greek sieges, looking at the role of women within the defending population. Scholarship has traditionally addressed the wartime representation of women like Andromache through a mythical lens. This chapter, by contrast, addresses historical women and historical sieges, conflicts such as the Carthaginian siege of Gela in $405 \mathrm{BC}$, and the Peloponnesian War. Focusing on women's roles in sieges, ranging from combat, to supply, subterfuge, and wall-building, it explores the direct contributions of women to siege warfare. In this chapter Martinez Morales emphasises how women, as members of the community, were an integral part of any city under siege, and places them in their appropriate wartime contexts.

Demetrius the Besieger is best known for his spectacular, but ultimately unsuccessful assault on Rhodes, an epic siege that earned him the sobriquet Poliorcetes, 'Besieger of Cities'. Despite Demetrius' military reputation and 'surname', Thomas C. Rose examines the career of Demetrius as a fortifier of cities rather than a city-taker. The mammoth siege towers and warships that Demetrius turned against the defences of cities and harbours have long been objects of fascination, but his construction of fortifications designed to be impregnable has received far less attention. As such, and as a good illustration of the symbiosis of attack and defence in the context of siege-warfare, his chapter examines Demetrius' innovative approach to both the attack and the defence of cities and doubles as a portrait of the state of the poliorcetic arts in the decades that followed the death of Alexander.

Shifting our gaze to the Roman world, Jeremy Armstrong's chapter investigates the origins of fortifications and siege warfare in archaic central Italy. Although fortifications and sieges form an important part of the literary narrative for early Roman history, the archaeological evidence offers a more ambiguous picture. While limited fortifications, typically of the agger and fossa variety, have been found in the region dating back to the early Iron Age, the wide scale use of full circuit walls seems to have been a relatively late development in the region, with most (including Rome's famous 'Servian Walls') only appearing in the late fifth and early fourth centuries BC. This is problematic, as the early types of fortification would not have offered the sort of continuous and defining civic boundary which Livy and other late republican historians seem to have 
envisaged, and would also not have represented a significant hurdle to an army attempting a determined siege or assault, as only portions of the community's perimeter would have been protected. Taking a holistic view of Roman society and warfare during the late sixth, fifth, and early fourth centuries BC, Armstrong argues that Rome's changing approach to, and use of, fortifications, was a direct reflection of a wider shift in central Italian warfare from a low-intensity, clanbased raiding ethos towards a high-intensity, state-focused approach.

James Crooks' chapter explores a key aspect of the narrative for early Roman sieges, the siege of Veii c. $400 \mathrm{BC}$, and how the intense atmosphere of a siege may have helped spark military (and social) innovation in Rome. The siege of Veii has always been remembered as a major turning point for the Roman military. It represents the first time that the Roman army is recorded as conducting and maintaining a supposedly continuous campaign over the course of multiple years to enact a single goal - the capture and sacking of their closest major military and economic rival. The central aspect of this campaign, a long-term siege of a major city, created a new set of challenges for the Roman armymost notably their ability to keep enough soldiers in the field for such a long period of time. This chapter argues that, in the context of the siege, the Romans began to increasingly use irregular forms of recruitment which did not seem to have required the calling of an official dilectus. These irregular troops, typically volunteers (literally voluntarii), were the key to Rome's victory, and their utilisation here may have laid the grounds for further Roman military developments in the following century.

Moving to the late Republic, Duncan B. Campbell analyses some of the most famous siege narratives in Roman history, those of Caesar. In this study, Campbell argues that while modern summaries of Caesar's siegecraft often concentrate on the example of Alesia, this siege was actually atypical. However, and paradoxically, there has been a simultaneous tendency amongst researchers to emphasise more aggressive assaulting strategies and to downplay any Roman willingness to engage in a blockade. In this chapter Campbell presents the detailed accounts of 29 sieges carried out in the years $58-45$ BC, in a methodical investigation into Roman besieging practice in the Caesarian period, which emphasises the ability of the Romans to use their technological and engineering skills in assessing which strategy to deploy in a particular siege context.

In the final chapter looking at the Roman world, Conor Whately discusses Procopius' account of the siege of Rome in AD 537/538, reinforcing the civilian involvement in, and reception of, sieges. This siege, which came in the early stages of the East Roman conquest of Italy, involved the defence of Rome by the general Belisarius against Wittigis and the Ostrogothic forces. The siege takes 
up nearly an entire book of Procopius' eight-book Wars, running from 5.18.1 to 6.10.20, and serves as the high mark of the text in terms of both tension and literary flair. Additionally, by all accounts the historian Procopius himself was a witness to the extraordinary events that he describes and so, by the standards of ancient historiography that held personal autopsy in such high regard, this account should rate highly. The epic nature of the description of the siege, however, raises concerns about the usefulness of the narrative to modern scholars interested in the late antique siege. This chapter examines the utility of Procopius' account for our understanding of the general course and experiences of a late-antique siege and whether his literary proclivities impinged upon his historical accuracy.

Moving towards an overview of the siege and its later history, Josh Levithan discusses the reception of the classical siege in later periods, down to the nineteenth century. Levithan sees the Italian Renaissance as a crucial way-station between the ancient and modern worlds. Improving guns for example from the sixteenth to nineteenth centuries-more effective, now, against walls than the catapult/battering ram/trebuchet technologies of the past-forced a new arms race. Fortifications were adapted, and the new balance which stretched from the sixteenth through the early nineteenth century featured siege assaults surprisingly similar to those from those of the Roman era. There was a parallel struggle of literary adaptation in the same period, as epic poetry returned attention to the siege, both real and imagined. After examining the influence of the classical siege on two epic accounts, Ariosto's Orlando Furioso and Tasso's La Gerusalemme Liberata, Levithan's study concludes with a look at the continuing influence of Roman siege narratives. The epic tradition, the indirect influence of the Roman handbook writer Vegetius, and Caesar's ubiquity in the modern Latin curriculum meant that the representation of Roman sieges continued to shape the writing of modern siege warfare.

Finally, Fernando Echeverría offers an overview of the study of sieges in the ancient Mediteranean, specifically as represented by this volume. He highlights the important role of comparative studies concerning all ancient history, and indeed in military history more generally. At the same time he warns against modernising tendencies when considering ancient sieges generally. Of course, he is well aware of the challenges of our evidence and in marrying both the literary sources and archaeological ones. Echeverría rightly notices that our impressions of ancient siege warfare mirror the state of our sources, and thus he rightly stresses, alongside several chapters in the volume, that early historical events (and indeed some later ones) are shrouded in mystery and maybe the absence of evidence is not necessarily evidence of absence for early siege technology. Early societies may well have developed significant defensive struc- 
tures alongside contemporary siege techniques. In this way, he raises important questions concerning the relationship between our evidence and ancient realities, between pictorial and archaeological images of sieges, and the textual evidence we have for them - and, of course, ultimately between fiction and reality. Finally, he warns against seeing the siege as a stand-alone and, therefore, isolated military experience. He rightly, we think, sees sieges (like the great setpiece battles of antiquity) as simply part of a continuum of ongoing warfare, an extreme moment, but an event deeply interconnected with both ongoing military action and the wider societies engaged in it.

As noted previously, this volume cannot hope to-nor does it attempt topresent a comprehensive overview of the ancient seige. While an effort has been made to offer a broad coverage, there are obviously significant holes and ommisions. That stated, we hope this breadth of coverage will contribute to the understanding of ancient siege warfare in the context of military encounters and society more generally. The word 'Companion' in the title, should therefore not be taken as an indication of comprehensiveness, but rather in a more corporate sense. In conclusion, the editors would suggest that sieges should be seen as an integral part of the wider military experience and of course as the paradigm of total war from an ancient perspective. As Fernando Echeverría points out, it is dangerous to isolate sieges from other kinds of military experience, and dangerous too to see the siege in a vacuum and separated from other forms of organised violence. This volume demonstrates that, from earliest antiquity to the later Roman Empire and its Renaissance legacy, the siege was integral to social, economic, and military activity in antiquity. It was social in that it required the community to come together in defence (and perhaps even to lay the foundation for sustained attack); economic in the use of enormous resources to prosecute sieges successfully; and militarily as an example of the high level of technical, engineering, and military skill employed to take cities by circumvallation and by storm. It should come as no surprise to anyone, given the importance of the city to ancient societies, that the siege and ancient civilisation go hand in hand from Troy to Jerusalem to the sack of Rome and Constantinople. 


\section{Bibliography}

Ballmer, A., Fernandez-Götz, M. and Mielke, D.P. (eds.) (2016) Understanding Ancient Fortifications: Between Regionality and Connectivity. Oxford.

Bernard, S. (2012) 'Continuing the Debate on Rome's Earliest Circuit Walls', PBSR 80: $1-44$.

Butterlin, P. and Rey, S. (2016) 'Mari and the Development of Complex Defensive Systems in Mesopotamia at the Dawn of History', in Frederiksen, Müth, Schneider and Schnelle (2016) 23-33.

Campbell, D. (2003) Greek and Roman Siege Machinery 399 BC-AD 363. Oxford.

Fontaine, S. and Helas, S. (eds.) (2016) Le fortificazioni arcaiche del Latium vetus e dell'Etrurie meridionale (IX-VI sec. a.C.): stratigrafia, cronologia e urbanizzazione. Rome.

Frederikson, R. (2016) 'Fortifications and the Archaic City in the Greek World', in Fontaine and Helas (2016) 252-266.

Frederiksen, R., Müth, S., Schneider, P.I., and Schnelle, M. (eds.) (2016) Focus On Fortifications: New Research on Fortifications in the Ancient Mediterranean and the Near East. Oxford.

Maher, M. (2017) The Fortification of Arkadian City States in the Classical and Hellenistic Periods. Oxford.

Pretzler, M. and N. Barley (eds.) (2017) Brill's Companion to Aineias Tacticus. Leiden.

Theocharaki, A.M. (2011) 'The Ancient Circuit Wall of Athens: Its Changing Course and the Phases of Construction', Hesperia 8o: 71-156.

Valbelle, D. (2001) 'A First Persian Period Fortress at Tell el-Herr', Egyptian Archaeology 18: 12-14.

Winter, F.E. (1971) Greek Fortifications. Toronto. 